\title{
Living longer: \\ Are we getting older or younger for longer?
}

\author{
Ana Amélia Camarano \\ Institute for Applied Economic Research, Brasília/DF, Brazil
}

\section{Abstract}

Since the second half of the 2oth century survival has been democratised in most countries. More and more people reach an advanced age. The objective of this paper is to discuss how phases of the life cycle are being re-defined in the context of a world in transformation: the universalization of social security that guarantees income for older people; technological advances that have increased the velocity of communication and the demand for continuing education; medical advances; and changes in family organization such as an increase in divorce rates, re-marriage and unions between people of the same sex. Even so, the biological changes that accompany ageing have not changed since Antiquity, in spite of hopes for a longer life. These changes occur later in life and more people live through them. Yet people continue to retire at more or less the same age. This suggests the creation of a new post retirement life phase that is distinct from adult life and the phase of fragility. We remain young for longer; indeed youth has been extended. We do not know whether this new phase will be experienced by all people. But if that becomes the case, why not include it as part of adult life?

Keywords: old age, retirement, active ageing, life cycle, third age. 


\section{Resumo}

A partir da segunda metade do século passado, a sobrevivência democratizou-se em grande parte dos países do mundo. Mais e mais pessoas estão alcançando as idades avançadas. Este trabalho tem por objetivo discutir como as fases da vida estão sendo re-desenhadas em face dessas mudanças num mundo que também se transforma: a universalização da Seguridade Social que garantiu renda para os idosos; o avanço tecnológico que aumentou a velocidade das informações e a demanda por uma educação continuada; avanços médicos; e mudanças familiares, com o aumento dos divórcios, dos recasamentos e das uniões homoafetivas. No entanto, as características biológicas das pessoas que envelhecem continuam as mesmas desde a Antiguidade, não obstante os grandes ganhos observados na esperança de vida. Mudou a idade em que se iniciam e, principalmente, o fato de que cada vez mais pessoas a vivenciam. $O$ seu adiamento não foi acompanhado pela idade em que as pessoas se aposentam. Isto resultou num aumento da fase pós-laboral e justificou a criação de uma nova fase da vida distinta da vida adulta e da fase das fragilidades. Assim sendo, estamos ficando jovens por mais tempo; a juventude foi oficialmente prolongada. Ainda não se sabe se essa nova fase vale para todos. Se valer, por que não adicioná-la à vida adulta?

Palavras-chave: velhice, aposentadoria, envelhecimento ativo, ciclo de vida, terceira idade. 


\title{
Living longer: \\ Are we getting older or younger for longer?
}

\author{
Ana Amélia Camarano
}

\section{Introduction}

Living longer is not a new historical fact. In the Old Testament, the ancient patriarchs died at the age of 900 or even older (Poulain et al. 2015). Methuselah is one such example. Age was probably measured differently in those days. Even so, according to Poulain et al. (2015), were their years measured as in modern times, the age of these patriarchs at death would outstrip 100 years. In the eighteenth century, Luxdorph collected about 700 portraits of long-lived persons, whose ages ranged from 80 to 185 years. Most of these individuals had their ages scientifically verified. Although lower than those showed in Luxdorph's gallery, they were still high (Petersen and Jeune 2010, quoted by Young 2013). ${ }^{1}$ For instance, one person who was presented as reaching 111 years old actually lived to the age of 93, according to his baptismal certificate.

In addition to the records shown in Luxdorph's gallery, other examples can be cited, such as the appointment of an Archbishop of Canterbury at the age of 65 in the year 1005, who died in office aged 84 (Johnson 2004). Another example is the French philosopher, Voltaire, who also died at the age of 84 . In 1764, then 70 years old, he published one of his most important works, the Dictionnaire Philosophique, an encyclopaedia that launched the concept of the Enlightenment. ${ }^{2}$ Unlike modern times, living longer was a privilege of the few. Child mortality was very high: then as now, those who survived the first years of life had a greater chance of reaching an older age. In late nineteenth century Britain, for example, the majority of people aged 20 could expect to survive to 60 years of age (Johnson 2004).

What is new has been the democratization of survival in most parts of the world. This has been taking place since the second half of the twentieth century. More and more of those individuals not dying at a young age are subsequently reaching old age. In Brazil, for instance, in 1980, 30 out of 100 female live births could expect to reach the age of 80; in 2013, 55 could expect to do so. Over this period, therefore, Brazilian life expectancy rose by almost 12 years. Today, a Brazilian man can expect to live for 74 years and a woman to about her $80^{\text {th }}$ birthday. ${ }^{3}$ Moreover, there is still room for further increases in this indicator. In fact Camarano's projections (2014) suggest that it may rise by nine years over the next 40 years. This generates new prospects for the entire life-cycle and raises the question of how these 'new years' of life are being experienced.

The life-cycle has been changed profoundly not just by the increase in life expectancy. Other important changes have occurred during the last two centuries in the developed countries and affected other countries as well. Among others, we can cite the establishment of medical science, the triumph of reason and the guarantee of the social rights. These extended the life-cycle by controlling or eliminating a large number of

\footnotetext{
1 The Luxdorphs Gallery was not actually published at the time that it was produced. Three hundred years later, in 2010, Petersen and Jeune collected this material and published the book Icons of Longevity: Luxdorph`s Eighteenth Century Gallery of Long-livers.

2 http://www.biography.com/people/voltaire-9520178. Accessed 23 March 2015.

3 Author's estimates.
} 
diseases. Births were also controlled and the biological determination of social roles has also come under challenge. The life-cycle also became constituted around various social dimensions such as education, working hours, career patterns and the right to retirement (Castells 1999).

This paper discusses how life phases are being re-drawn in response to these changes listed above. More specifically, it seeks to assess which phase has absorbed the highest gains in life expectancy. The text is divided into five sections, this introduction being the first. The second section analyses the ongoing changes in the various life-cycle phases. The third describes the two prevailing views concerning the final phase of life, or old age, asking whether this period should be split into two. The perspective of active aging is discussed in the fourth section, asking whether this can be seen as an extension of adulthood or a new phase. Final remarks are contained in the fifth section.

\section{Life stages}

The life-cycle approach assumes that individuals experience specific physical, psychological, cognitive and emotional needs in accordance with different stages of life. An individual's age is taken as a reference point marking the distinct phases of life. Generally speaking from a quantitative perspective, the analysis of changes in the life-cycle takes into account the timing, quantum and sequence of events (Billari 2001).

Since Antiquity, Western cultures have divided human life into phases in the attempt to establish some kind of order and predictability. Traditionally these phases were marked simply by biological events such as puberty, menarche, motherhood, menopause, senility and death. Over the course of history, the modern state has taken over responsibility for these issues from private and family life and became the institution regulating the different life-cycle phases. Today the latter are regulated from birth to death with an emphasis on education, entering and leaving the labour market, and retirement (Debert 2010). Phases of life have thus become regulated by both biological and social factors. They have their own identities, different statuses and powers, and guide society in the organization of tasks, responsibilities and behaviours (Calasanti 2007).

Traditionally three phases of life are delineated: first (childhood and adolescence), second (adulthood) and third (old age). This division takes into account mainly the physical characteristics of individuals and their participation in the labour market. Palacios (2004) quotes two Renaissance paintings that immortalize these three phases: one by Ticiano (1488/1576) and another by Giorgioni (1477/1510). These paintings make very clear the physical differences between the individuals portrayed in each of the three phases.

Figure 1 shows the division of the life-cycle of Brazilian men into these three phases, based on their participation in social events linked to the labour market in 1980 and 2010. Only men were considered, since the aim is to study the relationship between labour and life phases, which is clearer among the male population, especially in 1980 . These phases are clearly marked by their participation in school, work and retirement. Moreover we can observe that the phases succeed each other in linear order and that there is the prevalence of these events throughout their lives is sequential. On the other hand, it is found that Brazilian men participated simultaneously in more than one event, which seems to be an increasing trend over time. The same finding has also been reported in other parts of the world. Nowadays people of all ages switch jobs much more easily and combine different activities (Martin \& Pearson 2005). This makes delimiting the different phases of life more difficult. 
Figure 1: Proportion of male individuals that participate in the main social events of the cycle according to age - Brazil

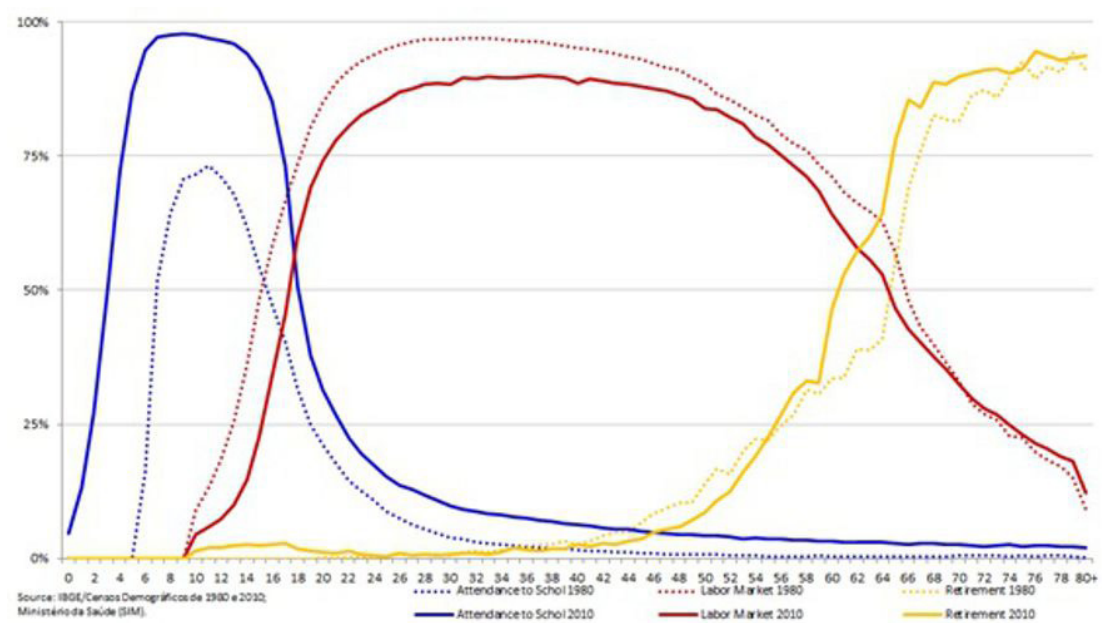

School attendance and participation in the labour market coincided for Brazilian men over the age of 16 in the two years under study and, in 2010, this lasted until almost the end of life. Over the age of 40 , one can observe an increasing proportion of retired men participating in the labour market. Brazilian law allows the retiree to return to the labour market without any restrictions. This is only prohibited for those who retire due to disability.

Several changes may be observed over the 30 years studied: men began to attend school earlier and leave later. As a result, they entered the labour market later too: the mean age for beginning economic activities rose from 16.0 to 17.6 years. Leaving work occurred earlier as well as retirement. The result, as shown in Figure 2, is that men are spending more time in school, less time in economic activities and receiving pensions for longer periods. Moreover, deaths are increasingly concentrated at extreme ages (Kanso 2014). A change can therefore be seen in the lifecycle, which for Sheehy (1995:4) amounts to a 'true revolution.'

Figure 2: Duration of events marking the life cycle - Brazil - Males

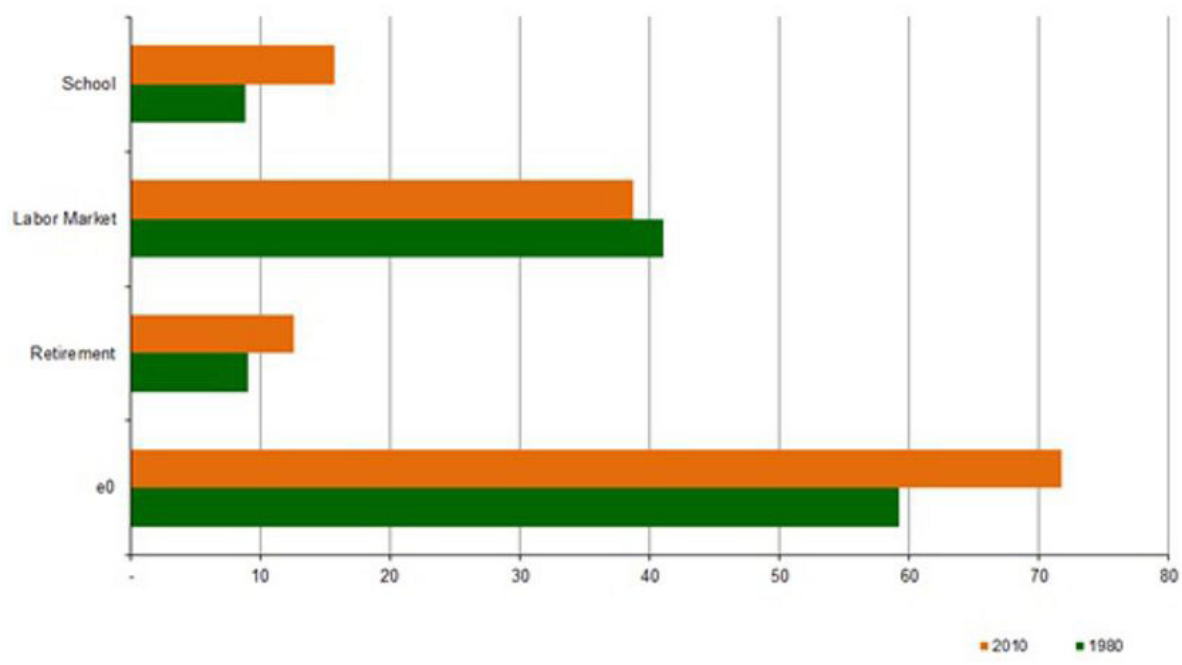

Source: IBGE Demographic Census of 1980 and 2010 
It is difficult to establish a single criterion, a watershed, separating one phase of life from another. They are not marked by clear processes. In many countries, chronological age has been used to regulate people's participation in several events such as the mandatory school age, the prohibition of child labour, the right to vote and the age of retirement. The Statute of the Child and Adolescent, as well as the Youth Statute and the Elderly Statute, together are a recognition by the Brazilian State that these age groups have their own needs and should be covered by specific public policies. Although the age criterion has many limitations, it has operational advantages and ease of verification, but it can result in discrimination and, in the case of the elderly, the feeling of "precocious dependence" (Camarano \& Medeiros 1999).

Sheehy (1995) argues that childhood is ending earlier; menarche and sexual life are occurring earlier and earlier. Furthermore children are increasingly adopting adult behaviours. Meyrowitz (1985, quoted by Debert 2010) suggests that the media is playing an important role by integrating informational worlds that were previously separate. Children are anticipating their access to the universe of young people and adults. This includes access to their language, clothing and leisure activities. The result is a shortening of childhood and the loss of its specificity as an age.

On the other hand, adolescence and youth are becoming longer. Madeira (2006) reasons that as a society develops, it demands more skills and the period of youth lengthens since individuals require more time to prepare for insertion in the productive sphere, i.e. the adult world. As mentioned earlier, in Brazil entry into the labour market has been postponed. As in many other countries, young people are leaving the parental home later. The mean age at which Brazilian men left their parents' home rose from 26.0 years in 1980 to 28.2 years in 2010. ${ }^{4}$ This generation is called the kangaroo, boomerang, yo-yo or parasite generation, among other terms. According to Lopes (1999), they are living a "sweet life."

As a consequence of these processes, Brazil's National Youth Policy in 2005 defined the age group 15-29 years as the young population. Assuming that adulthood starts later, the question becomes whether it ends later too. If the exit from adulthood is determined only by retirement, then this phase, Debert (2010: 65) writes, "is squeezed between an endless youth and an early retirement." In other words, it is shorter. This raises the question of its impact, taking into account the restrictive dynamic experienced by the Brazilian population, i.e. the slower growth rate of the labour force. But neither should studies of the transition to old age be limited to the relationship between work and retirement. If so, what marks the end of adult life and the beginning of old age?

On the contrary, retired individuals are looking for new forms of social integration. As Madeira (2006) records, men and women aged 6o years and over are attending university to train for professional occupations. In addition, we can observe an interest among seniors in computer learning, reflecting the benefits that it can offer to their lives (Kreis et al. 2007). As mentioned already, Brazilian law allows retirees to return to economic activities without any restrictions. Consequently, in 2013, about $34 \%$ out of retired men aged 60 to 69 years were working. ${ }^{5}$ This simultaneous participation blurs the boundaries between different phases of life, requiring new definitions of them, and also suggests the importance of setting a minimum retirement age in Brazil.

\footnotetext{
4 Author's estimates.

5 Data taken from the National Household Survey (PNAD) of 2013.
} 
What can be said is that this phase of life is the last and is formed by 'very aged persons'. It is assumed that old age brings physical, cognitive and mental vulnerabilities, a worsening of chronic and degenerative diseases, the loss of social roles following the withdrawal from economic activity, the appearance of new roles (as grandparents), wrinkles and grey hair, the loss of spouses, relatives and friends, a reversal of parental roles and the proximity of death. It means a change in physical and social roles.

The association between old age and physical frailty has gained strength since the second half of the nineteenth century (Tavares 2015), which may be associated with an increasing number of people surviving to advanced ages. The result is a more heterogeneous group of old persons, from both a physical and a social point of view, along with the emergence of old age as a social category. This has been associated with negative images (Debert 1999). But despite the huge medical progress observed throughout the twentieth century, combined with advances in education and the expansion of health service coverage, the frailties and losses brought about by old age have continued unchanged. They have been attenuated and/or delayed - in other words, old age has become older, but has not passed away. The postponement of these processes leads to questions about how the life course can be re-contextualized.

Sheehy (1995, quoted by Goldani 1999: 75) analysed the US case and concluded that: "The old boundaries and descriptions of adult life, beginning at 21 years old and ending at the age of 65 , are hopelessly outof-date. Think of the day when you turn 45 years old. This means that you will be in the childhood of a new life. Instead of being in decline, men and women would actually be starting a second adulthood and gradually passing to a life of greater meaning, renewed joy and creativity that goes far beyond the menopause of men and women. This second adulthood could be divided in two: the Age of Mastery (from 45 to 64 years) and the Age of Integrity (from 65 to 85 years). People become old only when they are very close to dying." This is the result not only of an increase in life expectancy, but also improvements in health conditions and personal autonomy, the universalization of Social Security and other social changes. All this has allowed the emergence of the third age as a category.

The third age category was born in France and England around 1950, though it only gained legitimacy in the 1980 (Silva 2008). It classifies individuals who are no longer of working age yet do not present signs of senility or decrepitude (Camarano \& Medeiros 1999). This phase may be an ideal moment for new conquests and the pursuit of personal satisfaction - the age of the fulfilment according to Laslett (1996). The existence of the third age depends, the latter author argues, not only on a prolonged life, but also on the existence of a community of retirees who play important roles in society.

During the 1960 and 1970s, the French urban middle classes started to become part of the retiree communities, previously composed mainly by low-skilled workers. As these middle classes had different consumption patterns and different social and cultural habits from the old retirees, they presented new demands, mainly in relation to leisure activities and preservation of the body (Silva 2008). Although this phenomenon is more readily observed in developed countries, there is evidence of its occurrence in Brazil too. Debert (1999), for example, showed that, especially since the 1980s, elderly people have become increasingly visible political actors in Brazilian society, obtaining a higher profile in the media and gaining the attention of the consumer, leisure and tourism industries. The idea of old age is no longer that of a time during which individuals are excluded from social life. As the period has become prolonged, the likelihood is that one portion (the younger and more educated elderly) have been experiencing these processes, while another portion is living through the final phase of life, with all its frailties. The latter could be termed the fourth age, or traditional old age. 
If one accept that chronological age defines the different phases of life, the question raised is which age marks the entrance into old age, or into the third and fourth ages. Legal frameworks consider just one phase. The World Health Organization (WHO) defines the elderly population in developed countries as the population aged 65 years or over and in less developed countries as those aged 60 years or over. Brazilian federal policies (National Policy for the Elderly and the Elderly Statute) ${ }^{6}$ define as elderly anyone aged 60 years old or over. This phase of life has also lengthened. Life expectancy at the age of 60 increased by about five years between 1980 and 2013, from 16.7 years to 21.3 years. ${ }^{7}$ This means that at the age of 60 individuals enter into a longer phase of life, longer than childhood and adolescence combined, one that is experienced by a large majority of elders. The length of this phase and its irreversibility was observed by Millôr Fernandes (1994):

"Childhood no, childhood is short-lived. Youth no, youth is fleeting. Old age yes. When a guy gets old, it's for the rest of his life and each day he gets older."

\section{Has old age changed: has it become older or died?}

The answer to this question requires understanding the changes in the social role of elderly people. The commonly-held view is that a 'golden age' once existed, especially in primitive cultures, when elders were respected on account of the wisdom accumulated as they aged. This was probably due to their low number, which made those who survived more selective in terms of their health and consequently their social roles. Since the late nineteenth century, though, the life course in Western cultures has become increasingly institutionalized, particularly in the spheres of school, work and retirement, and the perception of older people has become one of social marginalization. This process has coincided with the expansion of this demographic sector. In this view, modern capitalist economies marginalize older people, encouraging their retirement and inactivity, typically resulting in the decline of their economic situation. This perspective considers that, on average, a male worker becomes unproductive at the age of 65 years, although it is common to find individuals at this age or even older with a broad spectrum of skills (MacNicoll 2006, quoted in Goldani 2010). ${ }^{8}$

Cuddy et al. (2005, quoted in Goldani 2010) proposed four mechanisms by which this process occurs. The first is medical progress. This reduces mortality, which in turn increases the size of the elderly population and institutionalizes their retirement from the labour market, meaning that older people withdraw from higher social status occupations. Higher survival rates may result in a greater heterogeneity of this population with increased participation of individuals with reduced physical, mental and cognitive abilities. The second mechanism proposed by Cuddy et al. assumes that older people find it more difficult to keep up with technological advances since they lack access to the new and most prestigious jobs. The third is the greater spatial mobility of the younger population, which weakens ties with older relatives. And fourth and finally, the increased education of the population as a whole renders the oral tradition obsolete and diminishes the social position of old people as those with wisdom. Retirement, associated with leaving the labour market, entails not just a lower income but also a loss of social role, especially for men. By the

\footnotetext{
6 Brazil, 1994 and 2003 .

7 Author's estimates.

8 Since very few people survived to advanced ages in the past, their socioeconomic status and health/autonomy indicated selectivity and valorisation. Johnson (2004), for example, mentions that in the late nineteenth century both the British Prime Minister and the Queen of England were aged 8o and over.
} 
late nineteenth century, everyone who could work did so. But while about $75 \%$ of English men aged 65 or more were working in 1880 , this proportion dropped to $8 \%$ by 1991 . We should also note that leave from economic activity occurs not only from retirement but also as a result of discrimination in the labour market (Johnson 2004).

In the late twentieth century, many countries, including Brazil, saw a much larger number of people reaching advanced ages in relatively good health and going on to enjoy a longer period of retirement, which also became more comfortable from the economic point of view as social security coverage and the value of pensions and benefits increased. This has resulted in the prevalence in both the collective and individual imagination of two polarized views of old age (Townsend, Godfrey \& Denby 2006, Lloyd-Sherlock 2004).

The traditional view, still the most important, takes a negative view of elders and old age. The association between age and disease, or bodily degeneration, is largely responsible for this pessimistic view. "Old age scares" in Barros's words (2000: 7). The elderly population is seen as dependent and vulnerable, both economically and in terms of their declining health and lack of autonomy, compounded by an absence of social roles: in other words, all they experience are losses. The most important are the loss of the ability to work and of personal autonomy to undertake everyday activities. The perception of the elderly as intrinsically unproductive suggests that even if aging is desirable from an individual perspective, the growth of the elderly population can cause a burden on the young generations with the cost of supporting older people threatening the future prosperity of nations. ${ }^{9}$

The biological or social events that mark the individual's entry into different stages of life, such as the menarche and the menopause, the first job and retirement, are evaluated distinctly by society. We can also mention leaving home as a defining event in these phases. For young people, leaving the parental home marks the beginning of adulthood and their independence and is generally celebrated. For old people, though, leaving their homes to live in an institution or with relatives marks the entry into a final period of frailties and economic and/or biological 'dependence.' In addition, difficulties such as physical mobility, common to children and the elderly alike, are perceived differently depending on the age at which they occur (Sheets 2005, quoted in Calasanti 2007).

Adulthood is the 'prime age.' This is the life phase considered to be the healthiest, the time when an individual's physical and functional capabilities reach their maximum. In general, this peak is considered to be between 20 and 35 years old. From this age on, these conditions begin to deteriorate. ${ }^{10}$ Childhood and youth are preparatory phases for adult life, which also characterizes the independence of individuals. On the other hand, leaving adult life due to advanced age and/or the decline of the body marks the entry into another phase of dependence and frailty as well as the proximity of death. Little is known about the 'preparation' for entering this phase and how this transition occurs. Active aging programs aim to postpone the entry into this period of life. Brazil's Retirement Preparation Programs, ${ }^{11}$ for example, seek to emphasize the advantages presented to senior citizens in contemporary societies.

Notably the characteristics of old age are not only identified with what happens to the body. Being 'old' is not only assumed to situate individuals at a given point of the organic life-cycle, but also at a certain point in the course of social life. The classification of 'old' identifies people in various spheres of social life, including work, the family and so on. It is assumed that the representations of old age and the social

\footnotetext{
9 For an alarmist view of population aging, see: World Bank (1994) and Petersen (1999), cited in Lloyd-Sherlock (2004).

10 Wikipedia, the free encyclopedia/en.wikipedia.org/wiki/Young adult(psychology). Accessed in 03/17th/2015.

11 In Portuguese, Programa de Preparação para a Aposentadoria (PPA).
} 
position of elders in society are historically and socially determined categories (Camarano \& Medeiros 1999). In other words, 'dependence' goes beyond purely biological aspects. It is a result of a particular labour division and social structure. In industrial societies, 'independence' and the social role of individuals are associated with their participation in the labour market and also their productivity (Camarano \& Medeiros 1999). Consequently, 'dependence' may contain a socially constructed component linked to the negative paradigm linked to old people, such as discrimination in the labour market. Policies often reinforce this dependence (Walker 1991). For some countries like Brazil, such discrimination is expressed, among other ways, through forms of social control like mandatory retirement.

However, the negative viewpoint was important in terms of placing the issue of demographic aging on the public policy agenda and legitimizing a number of social rights such as universal pensions, special queues for the elderly, reserved seats on public transport, parking spaces, free urban transport, half-price admissions for cultural events and so on (Camarano 2013). Over the past 30 years, the extension of social welfare in Brazil and the improvements seen in the population's living and health conditions have resulted in another major social change: the dissociation of aging from poverty and the isolation of the elderly from the social sphere. The universalization of social security has not only provided a solution to income generation for the population who lose their labour capacity, it has also helped provide cultural, social and psychological care for a population that had previously been marginalized in society (Debert 2010). Leisure centres and universities for senior citizens have become widespread in Brazil.. ${ }^{12}$ As a result, retirement time is no longer a time for resting and self-communion, it has become a period of activity and leisure (Debert 2010). This has created opportunities for new, collective experiences of aging. These include the possibility for self-expression, more rewarding experiences and relationships, and the exploration of identities typical of young people ${ }^{13}$ (Debert 2010). This has provided the basis for a new view of aging.

Images of poor elderly people sitting on park benches and/or in the grounds of old people's homes were all-pervasive until recently. The contemporary depiction of this age group, by contrast, shows old people who dress like the young, have sex, follow special diets, engage in physical activity and are active travellers (Oberg \& Tornstam 2001, quoted by Townsend, Godfrey \& Denby 2006). An advertisement for a property in a condominium designed for retirees in the United States offered to potential buyers the dream of not aging: "the return of youth, sexual life, money, health and good memory." ${ }^{14}$ It is worth stressing, of course, that this announcement is directed to healthy, middle-class and white retired folk. "This idealized representation of aging is exclusionary," as McHugh points out (2003: 117, quoted by Townsend, Godfrey \& Denby 2006: 884).

These attempts to confront old age are not new, of course (Haber 2001/2002, quoted in Calasanti 2007; Goldenberg 2007, quoted in Tavares 2015). Metchnikoff (1977 quoted in Groisman 2015), the father of Gerontology, believed it possible to reduce or abolish the causes of premature senility, intemperance and disease. This would mean that pensions for people in their sixties and seventies would no longer be necessary and the costs of supporting the old could be reduced. What is new today is that technological

12 The first University of the Third Age was founded in France in the late 1960 s as a space for cultural and social activities, in order to fill old people's free time. The first University focused on teaching and research was inaugurated in 1973 in Toulouse (Peixoto 1998 and Silva 2008). In Brazil, São Paulo’s SESC opened colleges for senior citizens in the late 1970s. These offered courses designed to discuss topical issues related to aging. In the following decade, many universities set up colleges and open universities for seniors (Assis, Dias \& Necha, mimeo). In Brazil today there are at least 150 programs like these (Veras \& Caldas 2004).

13 Author's emphasis.

14 Townsend, Godfrey \& Denby 2006: 884. 
progress offers a wide range of alternative means for preventing or reducing the body's aging. The assumption is that many of the physical characteristics of aging can be minimized or eliminated: "Aging can be controlled, as it should be" (Calasanti 2007: 342). According to Marques (2004, p 66), "grey hairs can be treated to restore their colour and lustre; wrinkles can be reduced through laser applications or scalpels; diseases brought about by old age, such as those linked to bone degeneration or a debilitated circulatory system, can be safely controlled through physiotherapy, clinical treatments and/or medication.”

From this perspective, elders are seen as a specific consumer group. The central attraction here is the body's self-preservation. The promise of eternal youth is an important mechanism in the formation of this market. One outcome has been the growth of the anti-aging industry in the western world, now already a billion-dollar sector (Calasanti 2007). ${ }^{15}$ Consequently, as Debert (1999) argues, youth has lost its identity as a specific age group and become both a value and an asset to be achieved through the adoption of appropriate lifestyles and forms of consumption.

Furthermore, individuals are encouraged to pay constant attention to their body and to monitor and control their own health, particularly self-inflicted diseases linked to the physical harm caused by heavy drinking, smoking, a lack of physical activity and so on (Debert 1999). Although this vision is presented as antagonistic to the former, since it argues for the empowerment of elderly people, it paradoxically reinforces negative views of old age. In other words, by proposing measures to combat the 'negative' characteristics of aging, it reinforces negative stereotypes of older people as unproductive consumers of society's resources (Ranzijn 2010).

Pressures for resisting and denying the process of aging are stronger among women, a phenomenon that occurs throughout their life course. The 'need' for a good or youthful appearance increases as the woman ages, especially for heterosexual women competing with younger females for a partner (Calasanti 2007). The male tendency to marry younger women results in the fact that, in a recent survey, $75.2 \%$ of elderly Brazilian men had a spouse while only $41.7 \%$ of elderly women did so. ${ }^{16}$

In short, one could say that one is faced with a "bi-polar vision of old age" that "is laden with moral implications: a good old age with health, virtue, self-confidence, salvation is opposed to a poor old age with disease, sin, addiction, premature death and damnation" (Cole1992: 230). Whatever the case, both views consider old age to be a phase of life in which the elderly population forms a homogenous group with common needs and isolated from the rest of society. While the 'frail elderly' vision is a static view that ignores major technological advances, particularly in medicine, combined with the widespread coverage of health services and social security, the 'young elderly' vision fails to offer tools to understand the decline of cognitive and emotional skills and physical control that form an inevitable part of the natural life-cycle. It denies the differences between individuals and ignores or denies the natural losses caused by age. It proposes to extend activities and behaviours typical of adulthood or middle age as a counterpoint to the pessimistic view of aging.

Ranzijn (2010) stresses the importance of accepting the biological changes of aging without blaming elders for their lack of well-being. This does not mean that individuals and society as a whole should not go on looking for ways to maintain good health and to reduce the pathological aspects of ailments like dementia and vascular disease. But it is important to accept the decline brought by age as a natural part of the life-cycle.

15 The Special Committee of the American Senate Aging Affairs, using a narrow definition of this sector of industry, estimated its annual turnover to be 27 billion US dollars in 2001 (Calasanti 2007).

16 Calculated using data from the 2013 PNAD. 


\section{The extension of adulthood or old age: active or productive aging?}

This article's initial question concerned the phase that has most absorbed the gains in life expectancy. The second section showed that Brazilian men are spending more time at school and in retirement and less time in the labour market. Based on these criteria, can it be said that the adult life is becoming shorter? And if so, has old age been anticipated? Or has work lost its importance as an event definitive of adulthood? If so, what event now defines this phase?

As already mentioned, Brazilian legislation defines old age as starting at 6o. However, from 1994 - the year that the National Policy of the Elderly was established - to 2013, male life expectancy at birth increased by 6.0 years. Life expectancy at the age of 60 was estimated at 19.5 years in 2013, 2.9 years longer than in $1994 .{ }^{17}$ This increase has been accompanied by improvements in the physical, cognitive and mental conditions of the elderly population, as well as by improved social roles. Nonetheless, the age of mandatory retirement remained set at 70 years until December 2015, while the mean age at retirement declined from 64.1 to 59.7 years old between 1980 and 2010. The mean age at which individuals leave the labour market has also fallen.

The time spent by men with some disability remained constant between 1998 and 2008 at 2.6 years. Given the increase in life expectancy, it can be said that in relative terms men spend less time in a disabled condition, which does not therefore explain the 'shrinking' of adulthood. Figure 3 shows the proportion of Brazilian men aged 50 years or older who participated in the labour market in 1998 and 2008 and the proportion of men who experienced some difficulty in performing everyday activities. Both are disaggregated by age group. There was an evident decline in male participation rates, while the proportions of those with difficulties completing everyday activities remained constant. In other words, a reduction in the 'labour phase' was not matched by an increase in the period of physical frailties. Would it therefore be appropriate to change the criteria used to define the stages of life, such as participation in the labour market and/or delay in withdrawal from the same and/or entry into retirement? Camarano and Fernandes (2014) have shown that the number of men aged 50-69 years old not engaged in economic activities but also not retired has grown. ${ }^{18}$

17 In 1994, the population's life expectancy at birth was estimated at 68.1 years and in 2013, 74.1 years. Data estimated by the author.

18 A survey on male withdrawal from the labour market was conducted in the United States: $40 \%$ of respondents reported that they could have obtained a job in their field but they refused because of the low salary offered (Estado de São Paulo, 2014). 
Figure 3: Proportion of males who reprted having difficulties for the daily life activies (DLA) and of males who are in the labor force according to age groups - Brazil

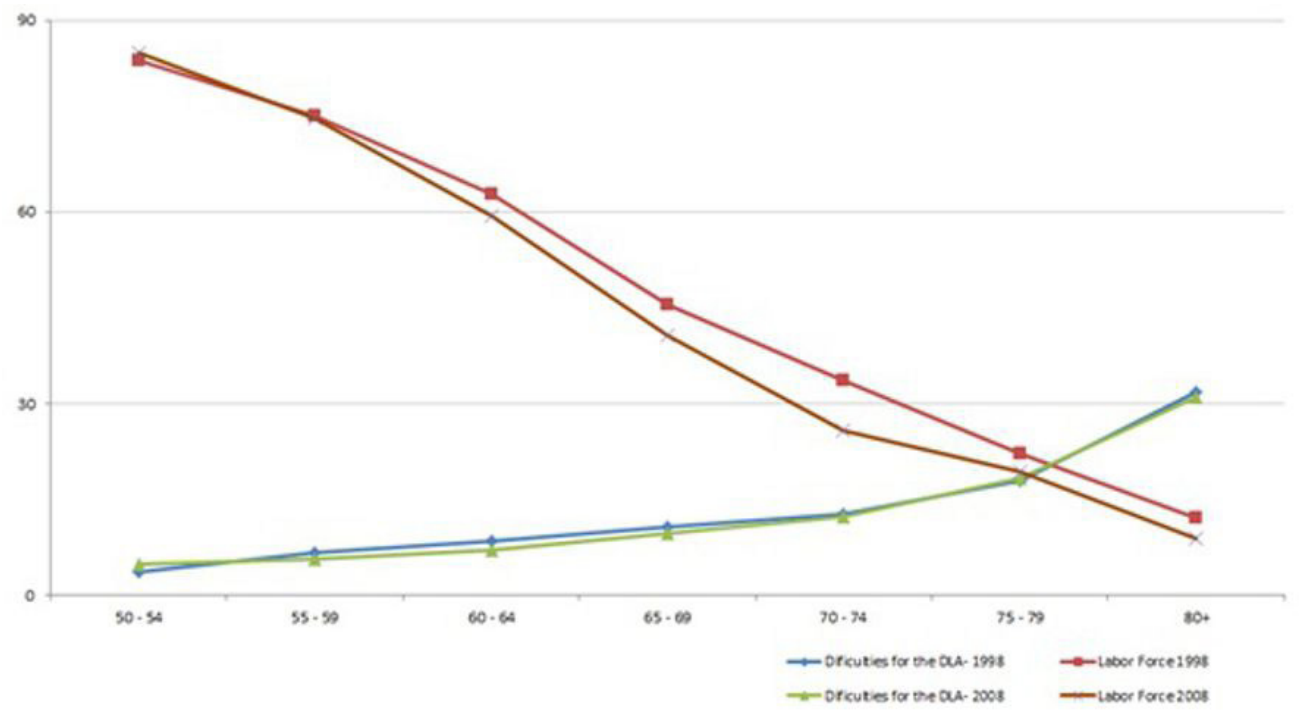

Source: IBGE/PNAD 1998 and 2008

As mentioned earlier, Sheehy (1995) proposes the idea of a second adulthood that can be divided into two phases. The first would comprise the age group from 45-65 years and could be called the Age of Mastery. In March 2014, the magazine Isto é published an issue with the cover story: "Everything is possible after the age of 50." According to the report: "Those in their fifties change jobs, start another college course, divorce, remarry..." ${ }^{19}$ In other words, they begin a new life. This issue considered 53 years old to be the entry point into middle age. In the nineteenth century, when a woman had reached 30 years old, she was already considered 'mature. ${ }^{20}$ Today the 50 year-old woman can do anything as the age of maturity is extended. CBN radio broadcast a program "How to be fifty - or more - full of energy and plans." Can these people in their fifties be described as enjoying a second adulthood, therefore, as Sheehy (1995) suggests? Is this new life being experienced by everyone?

Brazil's Retirement Preparation Programs (PPA) stress the importance of lifetime education to help retirees take up the new opportunities available to older people in contemporary societies. They do not evaluate their experience and propose that education should be an ongoing activity in an individual's life (Stucchi 2000). Figure 4 shows the proportions of men and women aged 50 or over who attended school in 1993 and 2013. These are higher among women and decrease as age increases. Although low, they rose in the time period under study, suggesting that these individuals, despite being at a later stage of life, are participating in events associated with younger people, pursuing new possibilities. Since their participation is very low, it may indicate a selectivity of these persons, which in turn may reflect an increase in inequalities within the elderly population..$^{21}$

\footnotetext{
19 Istoé, p.45.

20 Balzac wrote in 1832 "Women aged 30 years."

21 The participation in the Retirement Preparation Programs in Brazil is also limited to a relatively small group of workers in the formal sector of the economy. There is no national federal program. The existing programs are private enterprise initiatives, although the PNI establishes and encourages PPAs in the public and private sectors for individuals with a minimum of two years absence from the labour market.
} 
Figure 4: Proportion of Brazilian populationn who attends School by sex acoording to age groups

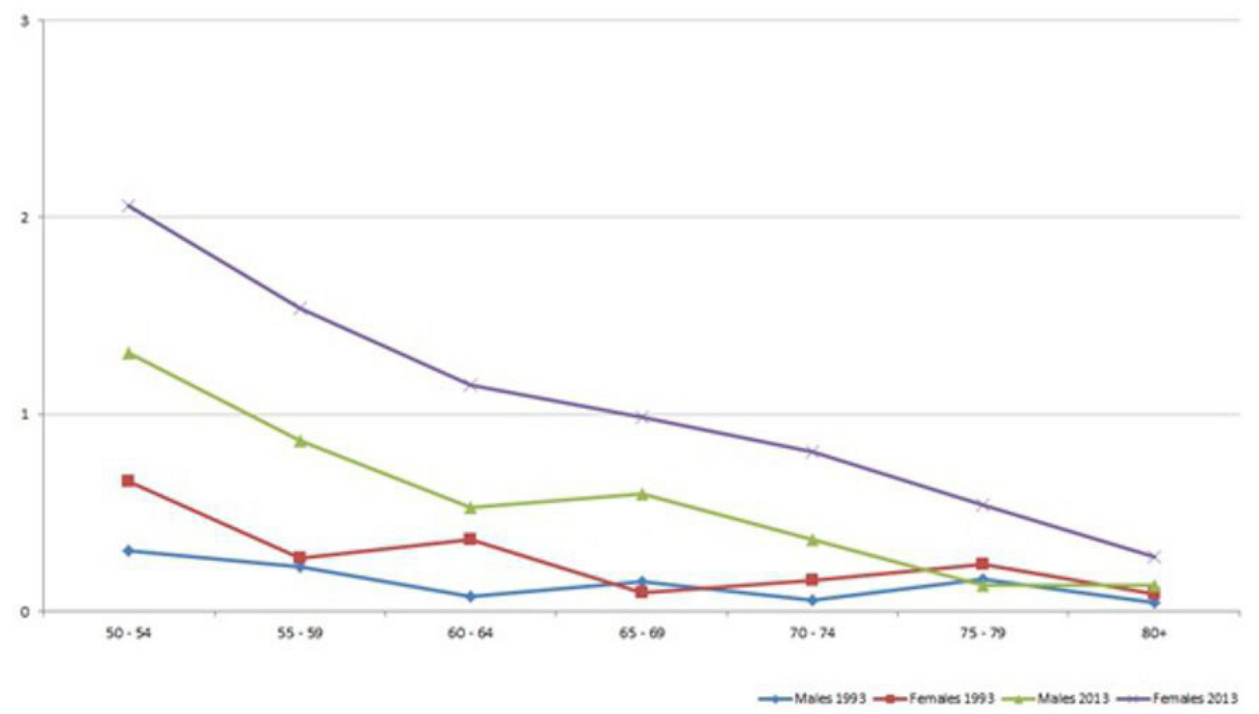

Source: IBGE/PNAD 1993 and 2013

It seems that one is facing by a contradiction. At the same time that this phase of life is seen as a 'new youth,' the individuals do not waive their right to retirement (Debert 2010), nor other rights, such as special queues, reserved seats on public transport and so on. All these rights are targeted at 'old' or 'fragile' persons: i.e. people who have lost the ability to work, have walking difficulties etc. (Camarano 2013). It is likely that the watershed defining entry into this phase of life remains 60 years due to the 'need' to preserve these rights. Hence the aging characteristics are denied but people still wish to be recognized as old.

Here the inequalities endemic to Brazilian society should be stressed, which result in people aging very differently. Two questions surface. The first is that retirement at 60 sets a very long phase of later life - approximately 22 years on average. This includes individuals up to the age of 100 . As a result, this age group is made up of very diverse kinds of people with distinct needs (Camarano 2013). The second is that over and above the heterogeneity brought about by age, this group is internally diverse in other ways due to differences in basic capacities (those that the individual was born with: genetic conditions, for example), life trajectories and the interrelationship between these capacities and the facilities/difficulties created by the environment in which the elderly find themselves, for example, public policies, prejudices and so on (Lloyd-Sherlock 2004). According to Neri (1993, p. 39), "the old Brazilian does not exist. There are several old age realities related to different conditions of individual and social life." Attention is also placed on differences in male and female aging, though this is not a topic for the present article.

Such heterogeneity justifies these views concerning old age as well as the consideration of two types of aging: active or successful, and fragile. However, the differences in these two types of aging are far from clear. The increase in life expectancy observed over the course of the twentieth century in developed societies was accompanied by a compression of morbidity in advanced ages, resulting in a double trend: better health and autonomy for the younger elderly, and increased debilities for older seniors. This leads to the conclusion that the health status of most young elderly people is satisfactory, but among the very old the prevalence of degenerative conditions as a result of senescence is high (Dooghe 1998 and Reves 1993, quoted in Avramov and Maskova 2003). Put otherwise, 'old age,' as measured by the presence of morbidity, has been delayed. So how should one define the interval between adulthood and this later period? 
In the United States in the 196os, the search for opportunities for this phase of life, combined with the need to transform the challenges ${ }^{22}$ posed by an aging population into opportunities for individuals and societies, led to the concept of productive or successful aging (Walker 2006 and Ranzijn 2010), ${ }^{23}$ primarily involving the adoption of behaviour typical to middle age at more and more advanced ages. This shift was given further impetus by the demands of elderly people for their post-employment phase to include something more than just entertainment and family obligations. Since leaving the labour market implies more free time available, the change can generate anguish and the loss of social roles, especially for men. ${ }^{24}$ This demand coincided with the concerns of policy makers regarding the increase in social security and health service spending. In this sense, extending productive life would meet the demands of both sides. Policy proposals were designed to remove disincentives that limited the participation of the elderly population in the labour market, barriers inhibiting their employment in part-time jobs, and incentives to early retirement (Walker 2002). The latter author also highlights the importance of actions to combat discrimination related to age, especially in the labour market. "Age discrimination is the antithesis of active aging. This form of exclusion is not only unjust but is an economic waste" (Walker 2002: 128).

In 1982, the Vienna Plan recognized the need to 'build' a new social actor - the elderly person - taking into account their needs and specificities (United Nations 1982). The concept of productive aging was expanded by the WHO and gave rise to the notion of active aging. This was defined (2002:13) as "the process of optimizing opportunities for health, participation and security in order to improve the quality of life as people get older." In addition to participating in the labour market, the concept includes physical capacity and the involvement of older people in social, economic, cultural, spiritual and civil issues (Ribeiro et al. 2009). It suggests a change in lifestyle to preserve the physical health conditions, over and beyond merely encouraging people to work for a longer time (Walker 2006). For the latter author, active aging is a strategy that combines a "morally correct [policy] with an economic goal" (2002: 121). Active aging is also frequently confused with successful aging as the differences between the two concepts are not very clear.

In Brazil, Article 27 of Chapter $\mathrm{V}$ of the Statute of the Elderly prohibits discrimination and any establishment of an age limit in open competitions for job openings, save in those cases where the nature of the job requires younger individuals. In addition, it specifies that the first tie-breaker in an open competition will be age, giving preference to the oldest candidate. Furthermore the 1988 Constitution also states that $10 \%$ of vacancies in open competitions should be allocated to people with special needs (Brazil 2003: 7).

The baby boomer generation, born in the 1950 and 1960 s, has begun to enter old age. According to Walker (2002), this was the generation most able to experience active aging. Its members have experienced large gains in education, especially women, who have actively participated in the labour market. The same also occurred in Brazil where, in addition, it was this generation who began to prepare for old age, unlike their parents and grandparents (Burlá et al. 2013). This generation was also much larger than the following one: hence their 'early' departure from the labour market may cause a shortage of labour and add to

22 Among these challenges, we can cite the reduction in the labour force, early exit from the labour market, pressure on social security systems and on healthcare and long-term care, and the social exclusion of vulnerable persons (Walker 2006).

23 In 1961 Havighurst introduced the concept of successful aging, associating it with activities that generate satisfaction and preserve health (Ribeiro et al. 2009).

24 Beauvoir (1990) states that young people experience the anxiety of entering the labour market and old people the anxiety of being expelled. Oliveira (1999) draws an analogy between the latter situation and the Janus statue. This has one face looking to freedom and the other to anxiety, uncertainty and the fear of death. 
pressures on the social security system. In other words, societies should take advantage of this opportunity, using their skills and resources.

Dillaway and Byrnes (2009) argue that active or successful aging is obtained by those individuals able to overcome personal barriers, which indeed is seen as their responsibility. ${ }^{25}$ This approach is encouraged through health policies that aim to reduce costs and keep individuals productive for longer. Although active aging seems to reflect a positive aspect of aging, its main purpose is to reduce the 'burden' to society of an increasing proportion of inactive individuals with health problems. As a result, Brazilian health policies for the elderly have emphasized active aging programs whose targets can be obtained through low-cost initiatives. These also encourage 'appropriate behaviour' from individuals over the course of their lives. The outcome is that those individuals who age with some degree of weakness or inability are considered responsible for this dependence. Moreover, states can thereby disclaim any responsibility in this area. Aging with a loss of capacities tends to be conceived, therefore, as a result of personal negligence and inadequate lifestyles (Debert 2010). In sum, aging is seen as a game that can be won or lost (Dillaway \& Byrnes 2009).

It can be asked whether in a country like Brazil, where social inequalities are high, this form of aging is benefiting the entire population. The resources required for this process to become possible are information, knowledge, education, good health, good care, access to community centres and gyms, all of which require good public transport and adequate financial resources. Given that a significant portion of the elderly and even Brazilian workers do not have access to these resources, they are effectively excluded from this form of aging. Leibing and Groisman (2001, in Leibing 2005: 28) quote an example obtained during interviews with elderly women in a favela in Rio de Janeiro. The women argued that the requirement to adopt a better diet, recommended to them by doctors to prevent high pressure, was 'illusory' given the higher costs involved. For Ranzijn (2010: 717), "active aging as a conceptual paradigm can marginalize significant segments of the elderly population." Moreover, this strategy can increase the inequalities that individuals experience throughout their lives. It also tends to accentuate gender differentials. The most important values for men are health, productivity and professional success. For women, a youthful appearance is also important. This means that some people age earlier and/or unlike others.

Authors stress that any idealization of what active and/or successful aging is may be counterproductive, oppressive and exclusionary. Indeed it may amount to a form of symbolic violence (Groisman 2015). Such idealization presents normative standards that can devalue those who do not live within their parameters (Stenner et al. 2012 and Walker 2002). Moreover, the measures proposed for active and productive aging deny the debilities natural to advanced age by proposing the adoption of behaviours and social roles typical to adult life by the elderly (Havighurst 1954, 1963, cited in Walker 2006).

\section{Final Remarks}

From what one has seen, it can be concluded that what is new in history is that more people are reaching advanced ages. This means that survival is more democratic, a phenomenon accompanied by the expansion of universal pensions. This process led to the construction of old age as a social category in the late nineteenth century. The new social category was born in close association with the institution of social security in 1880 in Germany. This was intended to remove people aged 70 or older from the labour market in order to make room for younger workers who would be at the peak of their productive life. For Bruns and

25 Author's emphasis. 
Abreu (1997), this kind of policy implied that society could define a 'good time,' 'a limit' to people's lives, and that getting older might entail becoming disposable and facing a social death (Santos 1990). Useful life is 'terminated.' The end result of these changes was a pessimistic view of old age.

In the 199os, a new vision emerged, seeking to define a social role for individuals at this stage of life, a 'usefulness' for them, denying their frailties. Roles typical of youth and adult life were proposed for this phase. Nevertheless, this new view has not relinquished the roles typically identified with aging, such as retirement, even in the case of individuals who still have a full capacity to work, i.e. those who retire 'precociously. ${ }^{26}$

The departure from the labour market of individuals exhibiting no signs of senility or decrepitude has been observed in various countries. This has led to the emergence of a new concept: the third age, defined by Laslett (1996) as the phase of fulfilment. Its existence, the author argues, depends on a 'retirement community' whose importance is recognized by society. Other changes, such as advances in medicine in general and cosmetic procedures in particular, as well as the potential for new personal relationships, greater leisure facilities, cultural activities and so on, have increased the possibilities for this age group. This process is associated with the inclusion of elderly individuals in various spheres of social life. It has also replaced the view that old age is a phase of losses with the idea that this phase provides a perfect moment for new achievements and the quest for personal satisfaction. What is different from adulthood is the withdrawal from the labour market. As such, the fourth age would be defined as the phase of frailties or losses. What seems to be new, then, is the dissociation of the departure of the labour market from the effective loss of labour capacity (the loss of importance of work?) and the maintenance of the characteristics and activities typical of adult life in this new phase.

The continuing rise in life expectancy means that more people now reach this phase, in turn making the elderly population more heterogeneous. This is taking place in a world that is also changing. Technological advancement has increased the speed of information and the demand for continuing education. The family has also changed, with an increase in divorces, remarriages and homosexual unions, while health conditions have improved too. All this has expanded the range of possibilities for both men and women throughout the life-cycle, including in old age, and allows the re-conceptualization of the life course.

Although increases in life expectancy can be identified among all social groups in Brazil, ${ }^{27}$ it does not seem that the new phase of life can be enjoyed by all. Many countries have not universalized their social welfare systems. Even in Brazil where this has occurred, $24.4 \%$ of the elderly failed to receive any social benefit in $2013 .{ }^{28}$ The search for eternal youth may also exacerbate the inequalities found in this phase of life since the resources needed are not available to everyone. This process is related to the 'obligation' to age actively, present in Brazilian health policies, which Debert (1999) argues means turning the right to choose in a duty, an obligation of every citizen. However "while obligation is equally distributed to all individuals, available resources for their exercise are not" (Debert 1999, p 66).

In sum, the biological characteristics of elderly people have remained the same since ancient times, despite the large gains observed in life expectancy. What is new is the fact that more individuals reach this phase and that the average age at which frailties start has been postponed. Their postponement has not accompanied the age at which people leave the labour market but has been accompanied by a denial of

26 This retirement is considered precocious because in Brazil, men begin to receive pensions, but spend four more years in the labour market (Camarano, Kanso and Fernandes 2012).

27 See Camarano et al. (2014).

28 Data taken from 2013 PNAD. If we take the population aged 65 and over, this proportion shrinks to $15.6 \%$. 
aging. By this criterion Brazilians are remaining younger for longer: youth has been officially prolonged. A new phase has also been added to the life-cycle, though it remains unknown whether this applies to everyone. But if so, why not add this phase to adulthood? If not, criteria other than chronological age should be used to classify old age.

Received 01/06/2015, approved 04/07/2015

\section{References}

ASSIS, Marcella G.; DIAS, Rosângela C.; NECHA, Ruth M. A universidade para terceira idade na construção da cidadania da pessoa idosa. Mimeo.

AVRAMOV, Dragana; MASKOVA, Miroslava. 2003. "Active ageing in Europe”. Population Studies, 41: 1-152. BARROS, Myriam M. L. 200o. Velhice ou terceira idade? Rio de Janeiro: Editora FGV. $2^{\text {nd }}$ edition.

BILLARI, Francesco C. 2001. "The analysis of early life courses: complex descriptions of the transition to adulthood". Journal of Population Research, 18(2): 119-142.

BEAUVOIR, Simone de. 1990. A velhice. Rio de Janeiro: Nova Fronteira.

BRASIL. Constituição Federal de 1988. Source: <http:/|www.planalto.gov.br>. Accessed 2 February 2015. . Lei no 8.069, de 13 de julho de 1990. Dispõe sobre o Estatuto da Criança e do Adolescente e dá outras providências. Source: 〈http://www.planalto.gov.br/ccivil_03/leis/18069.htm>. Accessed 2 February 2015. . Lei no 8.842, de 4 de janeiro de 1994. Dispõe sobre a Política Nacional do Idoso. Source: <http:/|www. planalto.gov.br/ccivil_03/leis/18842.htm>. Accessed 4 February 2015.

. Lei no 10.741, de 1 de outubro de 2003. Dispõe sobre o Estatuto do Idoso e dá outras providências. Source: 〈http:/|www.planalto.gov.br/ccivil_03/leis/2003/l10.741.htm>. Accessed 4 February 2015 . Lei $n^{\circ} 11.129$, de 30 de junho de 2005. Institui o Programa Nacional de Inclusão de Jovens - ProJovem; cria o Conselho Nacional da Juventude - CNJ e a Secretaria Nacional de Juventude; altera as Leis nos 10.683, de 28 de maio de 2003, e 10.429, de 24 de abril de 2002; e dá outras providências. Source: $<$ http:/l www.planalto.gov.br/ccivil_03/_Ato2004-2006/2005/Lei/L11129.htm>. Accessed 5 February 2015.

. Lei $n^{\circ} 12.852$, de 05 de agosto de 2013. Institui o Estatuto da Juventude e dispõe sobre os direitos dos jovens, os princípios e diretrizes das políticas públicas de juventude e o Sistema Nacional de Juventude SINAJUVE. Source: <http:/|www.planalto.gov.br/ccivil_03/_Ato2011-2014/2013/Lei/L12852.htm〉. Accessed 8 February 2015.

BRUNS, Maria A. T.; ABREU, Antonio S. 1997. "O envelhecimento: encantos e desencantos da aposentadoria". Revista ABOP, 1(1): 5-33.

BURLÁ, Claudia et al. 2013. "Panorama prospectivo das demências no Brasil: um enfoque demográfico". Ciênc. Saúde Coletiva, 18(2): 949-956.

CALASANTI, Toni M. 2007. "Bodacious berry, potency wood and the aging monster: Gender and age, relation in anti-aging ads". Social Forces, 86(1): 335-355.

CAMARANO, Ana A. 2013. Estatuto do Idoso: avanços com contradições. Rio de Janeiro: Ipea (Discussion paper 1840).

. 2014. "Perspectivas de crescimento da população brasileira e algumas implicações". In: (ed.), Novo regime demográfico: uma nova relação entre população e desenvolvimento? Rio de Janeiro: Ipea. pp. 177210. 
-_-. et al. 2014. "Desigualdades na dinâmica demográfica e as suas implicações na distribuição de renda no Brasil". In: A. A. Camarano (ed.), Novo regime demográfico: uma nova relação entre população e desenvolvimento? Rio de Janeiro: Ipea. pp. 241-270.

.; FERNANDES, Daniele. 2014. "O que estão fazendo os homens maduros que não trabalham, não procuram trabalho e não são aposentados?” Boletim de Mercado de Trabalho: conjuntura e análise, 57: 21-30. .; KANSO, Solange; FERNANDES, Daniele. 2012. "Saída do mercado de trabalho: qual é a idade?" Boletim de Mercado de trabalho: conjuntura e análise, 51: 27-36. .; MEDEIROS, Marcelo. 1999. "Introdução". In: A. A. Camarano (ed.), Muito além dos 6o: os novos idosos brasileiros. Rio de Janeiro: Ipea. pp. 1-15.

.; MELLO, Juliana L. 2006. "Introdução”. In: A. A. Camarano (ed.),Transição para a vida adulta ou vida adulta em transição? Rio de Janeiro: Ipea. pp. 13-28.

CASTELLS, Manuel. 1999. Information technology, globalization and social development. Geneva: UNRISD (Discussion Paper 114).

COLE, Thomas R. 1992. The journey of life: a cultural history of aging in America. Cambridge: Cambridge University Press.

CUDDY, Amy J. C. et al. 2005. "This old stereotype: the pervasiveness and persistence of the elderly stereotype". Journal of Social Issues, 61(2): 265-283.

DEBERT, Guita. G. 1999. A reinvenção da velhice: socialização e processos de reprivatização do envelhecimento. São Paulo: Editora da Universidade de São Paulo/ FAPESP. 2010. "A dissolução da vida adulta e a juventude como valor". Horizontes Antropológicos, 16(34): 49-70.

DEPP, Colin A.; JESTE, Dilip V. 2009. "Definitions and predictors of successful aging: a comprehensive review of larger quantitative studies”. Focus, 7(1): 137-150.

DILLAWAY, Heather E.; BYRNES, Mary. 2009. "Reconsidering successful aging: a call for renewed and expanded academic critiques and conceptualizations". Journal of Applied Gerontology, 28(6): 702-722.

"HOMENS americanos desistem de trabalhar". Estado de São Paulo 2014; 15 dez. Source: http://economia. estadao.com.br/noticias/geral,homens-americanos-desistem-de-trabalhar-imp-,1607050. Accessed 22 December 2014.

FERNANDES, Millôr. 1994. Millôr definitivo - a biblia do caos. Porto Alegre: L \& PM Editores.

GOLDANI, Ana. M. 1999. "Mulheres e envelhecimento: desafios para os novos contratos intergeracionais e de gêneros". In: A. A. Camarano (ed.), Muito Além dos 6o: os novos idosos brasileiros. Rio de Janeiro: Ipea. pp: 75-113. 2010. "Ageism in Brazil. What is it? Who does it? What to do with it?" R. Bras. Est. Pop., 27(2):385405.

GOLDENBERG, Mirian. 2007. Nu \& vestido: dez antropólogos revelam a cultura do corpo carioca. Rio de Janeiro: Record.

GROISMAN, Daniel. 2015. O cuidado enquanto trabalho: envelhecimento, dependência e políticas para o bem-estar no Brasil. Phd thesis, Escola de Serviço Social - UFRJ.

HABER, Carole. 2001/2002. "Anti-aging: why now? A historical framework for understanding the contemporary enthusiasm".Generations, 25(4): 9-14.

HAVIGHURST, Robert. 1954. "Flexibility and the social roles of the retired". American Journal of Sociology, 59(4): 309-311. . 1963. "Successful ageing". In: R. Williams; C. Tibbitts; W. Donahue (ed.), Process of ageing, vol. 1, New York: Atherton. pp. 299-320. 
IBGE - INSTITUTO BRASILEIRO DE GEOGRAFIA E ESTATÍSTICA. 2014. Pesquisa Nacional por Amostra de Domicilios - PNAD 2013 - sample microdata.

JOHNSON, Paul. 2004. "Long-term historical changes in the status of elders: the United Kingdom as an exemplar of advanced industrial economies". In: P. Lloyd-Sherlock (ed.), Living longer: ageing, development and social protection. London/ New York: United Nations Research Institute for Social Development/Zed Books. pp. 22-43.

KANSO, Solange. 2014. “Compressão da mortalidade no Brasil”. In: A. A. Camarano (org.), Novo regime demográfico: uma nova relação entre população e desenvolvimento? Rio de Janeiro: Ipea. pp. 155-175.

KREIS, Rosana A. et al. 2007. “O impacto da informática na vida do idoso”. Revista Kairós, 10(2): 153-168.

LASLETT, Peter. 1996. "What is old age? Variation over time and between cultures". In: G. Caselli; A. D.

Lopez (ed.), International studies in demography: health and mortality among the elderly, issues for assessment. New York: Oxford University Press. pp. 21-38.

LEIBING, Annette. 2005. "The old lady from Ipanema: changing notions of old age in Brazil". Journal of Ageing Studies, 19: 15-31.

LEIBING, Annette; GROISMAN, Daniel. 2001. "Tão alto quanto o morro - identidades localizadas de mulheres hipertensas na Favela da Mangueira”. In: B. T. Ribeiro et al. (ed.), Narrativa , identidade e clínica. Rio de Janeiro: Edições IPUB/ CUCA. Pp258-276.

LLOYD-SHERLOCK, Peter. 2004. "Ageing, development and social protection: generalisations, myths and stereotypes". In: P. Lloyd-Sherlock (ed.), Living longer: ageing, development and social protection. London/ New York: United Nations Research Institute for Social Development/ Zed Books. pp. 1-17.

LOPES, Cláudio F. 1999. "A doce vida dos filhos-cangurus". Revista Galileu (online). http://galileu.globo.com/ edic/95/comportamento1.htm: Accessed 8 March 2014.

MACNICOLL, John. 2006. Age discrimination: an historical and contemporary analysis. Cambridge: Cambridge University Press.

MADEIRA, Felícia. R. 2006. "Educação e desigualdade no tempo de juventude”. In: A. A. Camarano (ed.),Transição para a vida adulta ou vida adulta em transição? Rio de Janeiro: Ipea. pp. 139-17o.

MARQUES, Ana M. 2004. "Velho/idoso: construindo o sujeito da terceira idade". Revista Esboços, 11(11): 65-71. MARTIN, John; PEARSON, Mark. 2005. "Time to change". OECD Observer; 248: 7-8.

McHUGH, Kevin. 2003. "Three faces of ageism: society, image and place”. Ageing \& Society, 23(2): 165-185. MEYROWITZ, Joshua. 1985. No sense of place: the impact of electronic media on social behavior. Oxford: Oxford University Press.

NACIONES UNIDAS. 1982. Plan de Acción Internacional sobre el Envejecimiento. Austria: Viena (Resolución $37 / 51)$.

NERI, Anita L. (ed.). 1993. Qualidade de vida e idade madura. Campinas: Papirus. $1^{\text {st }}$ edition.

ÖBERG, Peter; TORNSTAM, Lars. 2001. "Youthfulness and fitness: identity ideals for all ages?" Journal of Aging and Identity, 6(1): 15-29.

OLIVEIRA, Rosiska D. de. 1999. "Sobre direitos e privilégios". Folha de São Paulo, Tendências/Debates, Opinião 1-3, São Paulo.

OMS - ORGANIZAÇÃO MUNDIAL DA SAÚDE. 2002. Envelhecimento ativo: uma política da saúde/World Health Organization. Brasília/DF: Opas.

PALACIOS, Annamaria R. J. 2004. "Velhice, palavra quase proibida; terceira idade, expressão quase hegemônica: apontamentos sobre o conceito de mudança discursiva na publicidade contemporânea". In: Anais do Encontro da Associação Portuguesa de Linguística, 20, Lisbon. Mimeo. 
PEIXOTO, Clarice. 1998. "Entre o estigma e a compaixão e os termos classificatórios: velho, velhote, idoso, terceira idade...”. In: M. M. L. Barros (ed.), Velhice ou terceira idade? Rio de Janeiro: FGV.. $1^{\text {st }}$ edition. pp. 69-84.

PETERSEN, Lise-Lotte; JEUNE, Bernard. 2010. Icons of longevity: Luxdorph's eighteenth century gallery of longlivers. Odense: University Press of Southern Denmark.

PETERSEN, Peter. 1999. "Gray down: the global aging crisis". Foreign Affairs, 78(1): 42-55.

POULAIN, Michel et al. 2015. Extreme longevity in the past: validation of centenarians who died before WWI. In: Population Association of America - PAA 2015 Annual Meeting, San Diego, CA.

RANZIJN, Robert. 2010. "Active ageing - another way to oppress marginalized and disadvantaged elders? Aboriginal elders as a case study". Journal of Health Psychology, 15(5): 716-723.

“TUDO é possível aos 50 anos". Revista Isto É, 12 March 2014.

RIBEIRO, Priscila C. R. et al. 2009. "Variabilidade no envelhecimento ativo segundo gênero, idade e saúde". Psicologia em Estudo, 14(3): 501-509.

SANTOS, Maria F. S. 1990. Identidade e aposentadoria. São Paulo: Pedagógica e Universitária.

SHEEHY, Gail. 1995. New passages: mapping your life across time. New York: Ballantine Books.

SHEETS, Debra J. 2005. "Aging with disabilities: ageism and more". Generations, 29(3): 37-41.

SILVA, Luna R. F. 2008. "Da velhice à terceira idade: o percurso histórico das identidades atreladas ao processo de envelhecimento". História Ciências Saúde - Manguinhos, 15(1): 155-168.

STENNER, Paul et al. 2012. "Older people and 'active ageing': subjective aspects of ageing actively". Journal of Health Psychology, 16(3): 467-477.

STUCCHI, Deborah. 2000. "O curso da vida no contexto da lógica empresarial: juventude, maturidade e produtividade na definição pré-aposentadoria”. In: M. M. L. Barros (ed.), Velhice ou terceira idade? Rio de Janeiro: FGV. $2^{\text {nd }}$ edition. pp. 35-46.

TAVARES, Márcia F. 2015. Trabalho e longevidade: como o novo regime demográfico vai mudar a gestão de pessoas e a organização do trabalho. Rio de Janeiro: Qualitymark Editora.

TOWNSEND, Jean; GODFREY, Mary; DENBY, Tracy. 2006. “Heroines, villains and victims: older people’s perceptions of others". Ageing and Society, 26(6): 883-900.

VERAS, Renato P.; CALDAS, Célia P. 2004. "Promovendo a saúde e a cidadania do idoso: o movimento das universidades da terceira idade”. Ciência \& Saúde Coletiva, 9(2): 423-432.

WALKER, Alan. 1991. "The social construction of dependency in old age”. In: M. Loney et al. (eds.),The State or the market: politics and welfare in contemporary Britain. London: SAGE Publications. pp 41-57. . 2002. "A strategy for active ageing. Second world assembly on ageing". International Social Security Review, 55(1): 121-139. 2006. "Active ageing in employment: its meaning and potential". Asia-Pacific Review, 13(1): 78-92.

WORLD BANK.1994. Averting the old age crisis. Policies to protect the old and promote growth. Oxford: Oxford University Press.

YOUNG, Robert D. 2013. “The book that took 300 years to publish”. The Gerontologist, 53(1): 185-19o.

\section{Ana Amélia Camarano}

Institute for Applied Economic Research, Brasília/DF, Brazil

ana.camarano@ipea.gov.br 